\title{
Gingival Squamous Cell Carcinoma: a Case Report
}

\author{
Luiz Antonio Guimarães Cabral ${ }^{1}$, Luis Felipe das Chagas e Silva de Carvalho², José Antônio \\ Pereira Salgado ${ }^{3}$, Adriana Aigotti Haberbeck Brandão ${ }^{4}$, Janete Dias Almeida ${ }^{1}$
}

${ }^{1}$ Department of Biosciences and Oral Diagnosis, São José dos Campos Dental School, São Paulo State University - UNESP, São José dos Campos, São Paulo, Brazil.

${ }^{2}$ São Paulo State University - UNESP, São José dos Campos Dental School, Postgraduation Program in Oral Biopathology, São José dos Campos, São Paulo, Brazil and Federal University of ABC, Postgraduation Program in Nanosciences and Advanced Materials, Santo André, São Paulo, Brazil.

${ }^{3}$ Department of Social Science and Pediatric Dentistry, São José dos Campos Dental School, São Paulo State University UNESP, São José dos Campos, São Paulo, Brazil.

${ }^{4}$ Department of Biosciences and Oral Diagnosis, São José dos Campos Dental School, São Paulo State University - UNESP, São José dos Campos, São Paulo, Brazil.

\author{
Corresponding author: \\ Janete Dias Almeida \\ Faculdade de Odontologia de São José dos Campos - UNESP \\ Departamento de Biociências e Diagnóstico Bucal \\ Av. Francisco José Longo, 777 São Dimas, 12245-000, São José dos Campos, São Paulo \\ Brazil \\ Fax: 055211239479010 \\ E-mail: janete@,fosjc.unesp.br
}

\begin{abstract}
Background: Squamous cell carcinoma is a malignant epithelial neoplasm characterized by variable clinical manifestations. When located in the gingiva, this neoplasm may mimic common inflammatory lesions. The aim of this study was to report a case of atypical squamous cell carcinoma, in which the patient had no risk factors for the development of this neoplasm.

Methods: A 61 year old Caucasian female was seen with a 3 month history of a rapidly growing, painful nodule in the gingiva adjacent to tooth \#11. Clinical examination revealed a proliferative lesion in the vestibular marginal gingiva of teeth \#11 and $\# 12$, presenting with purulent exudation. Thus, in view of the clinical symptoms and differential diagnosis of an infectious granulomatous process and malignant neoplasm, an incisional biopsy was obtained from the lesion.

Results: The diagnosis of squamous cell carcinoma was made and fourteen days after incisional biopsy, healing was found to be unsatisfactory. The patient was referred for treatment consisting of surgical excision of the tumour. A removable partial denture was fabricated for rehabilitation, one month after surgery of the maxilla; the patient was submitted to dissection of the regional lymph nodes and radiotherapy for an additional 3 months. Three years after the end of treatment, the patient continues to be followed-up and does not show any sign of recurrence.

Conclusions: Gingival squamous cell carcinoma is a condition which chance of cure is higher when carcinomatous lesions are diagnosed and treated early. In this instance dentists play an important role in early detection of gingival squamous cell carcinoma.
\end{abstract}

Keywords: oral cancer; squamous cell carcinoma; gingival neoplasms; gingival recession; early detection of cancer.

\author{
Accepted for publication: 7 July 2010 \\ To cite this article: \\ Cabral LA, Carvalho LF, Salgado JA, Brandão AA, Almeida JD. Gingival Squamous Cell Carcinoma: a Case Report. \\ J Oral Maxillofac Res 2010 (Jul-Sep);1(3):e6 \\ URL: http://www.ejomr.org/JOMR/archives/2010/3/e6/e6ht.pdf \\ doi: $10.5037 /$ jomr.2010.1306
}




\section{INTRODUCTION}

Squamous cell carcinoma (SCC) is the most frequent malignant neoplasm affecting structures of the oral lining, which accounts for more than $90 \%$ of all malignant lesions in the mouth [1]. This neoplasm is generally more frequent in male than in female, but this is not observed in cases of SCC located in the gingival $[1,2]$. In general, SCC affects subjects after their fifth decade of life [2] .

Except for carcinoma of the lip vermilion, the most common sites of oral SCC are the tongue and floor of mouth, followed at a lower frequency by the soft palate, gingiva and buccal mucosa [3]. The etiology of SCC remains unknown, but predisposing factors such as smoking associated with heavy alcohol use are well known [1]. Other habits have also been associated with SCC, such as chewing betel leaves and inverted smoking, practices commonly observed in India [4].

The clinical characteristics of SCC vary from case to case and include the exophytic (verrucous or papillary), endophytic, ulcerated, leukoplastic, erythroplastic or erythroleukoplastic forms. Depending on their extent and/or location, these lesions may cause painful symptoms and resorption of adjacent bone seen as a "moth-eaten" appearance on radiographs. SCC of the gingiva is normally painless [5] and it is located in the keratinized portion. In advanced stages, it is aggressive and it has easy access to infratemporal fossa []. According to Yoon et al. []], the clinical aspect of oral SCC can range from a white plaque to an ulcerated lesion. Importantly, when located in the gingiva this type of malignant tumour may resemble inflammatory lesions frequently observed in this region.

Treatment of SCC of the gingiva is primarily surgical. Radical neck dissection, or its modification, is the standard treatment for the metastatic lymph nodes. Radiotherapy is usually not the preferred modality of treatment for early gingivobuccal complex cancer. It is used either postoperative adjuvant treatment or as definitive treatment for advanced cancer with or without chemotherapy. Chemotherapy has been used as neo-adjuvant, adjuvant or palliative treatment $[\underline{4}, \underline{8}, \underline{9}]$. Regardless of advances in diagnosis and treatment during the past 40 years, the overall 5 year survival rates for oral and oropharyngeal squamous cell cancer have only slightly improved and remain around 50\%. Thus, the early diagnosis and treatment of carcinoma by health care providers is essential in achieving a good prognosis [10].

Authors report here a case of SCC involving the maxillary gingiva in the region of the right maxillary central and lateral incisors.

\section{CASE DESCRIPTION AND RESULTS}

A 61 year old Caucasian female was seen at the Stomatology Clinic, Department of Biosciences and Oral Diagnosis, São José dos Campos Dental School, complaining of a growing "pellet". The patient reported irritation of the gingiva adjacent to tooth \#11 for 3 months, which developed into various yellow plaques, sometimes presenting a purulent discharge. The patient thus sought a periodontist, who performed root scaling and prescribed amoxicillin for 10 days. Since no changes in the clinical symptoms were observed, the dentist referred the patient to the above discipline.

Intraoral clinical examination showed recession of the marginal gingiva in the region of teeth \#11 and \#12 due to a proliferative lesion, with the observation of areas of yellow extravasation, which resulted in the discharge of pus in the vestibular region (Figure 1). No other periodontal involvement was detected; other mucous membranes were within the normal range. In view of the clinical aspects of the lesion, the differential diagnosis was of an infectious proliferative process caused by human pappilomavirus (HPV) and squamous cell carcinoma. An incisional biopsy was obtained from the lesion.

Histopathological analysis of biopsy specimen revealed a malignant neoplasia of epithelial origin characterized by invasive proliferation of nests and cords of neoplastic epithelial cells. These cells exhibited intense cellular and nuclear pleomorphism, nuclear hyperchromatism, loss of cells cohesion, multiple and clearly visible nucleoli, individual cell keratinization, atypical mitoses, and formation of keratin pearls. An intense and diffuse mononuclear inflammatory infiltrate, numerous blood vessels of various calibers and areas of hemorrhage and edema were observed in the fibrous connective tissue stroma.

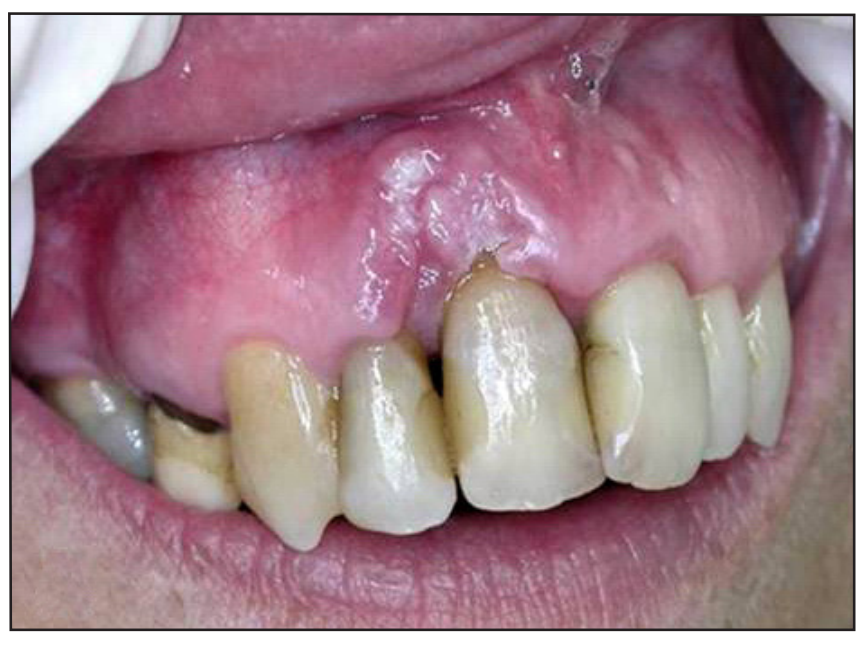

Figure 1. Clinical presentation of the lesion described. 

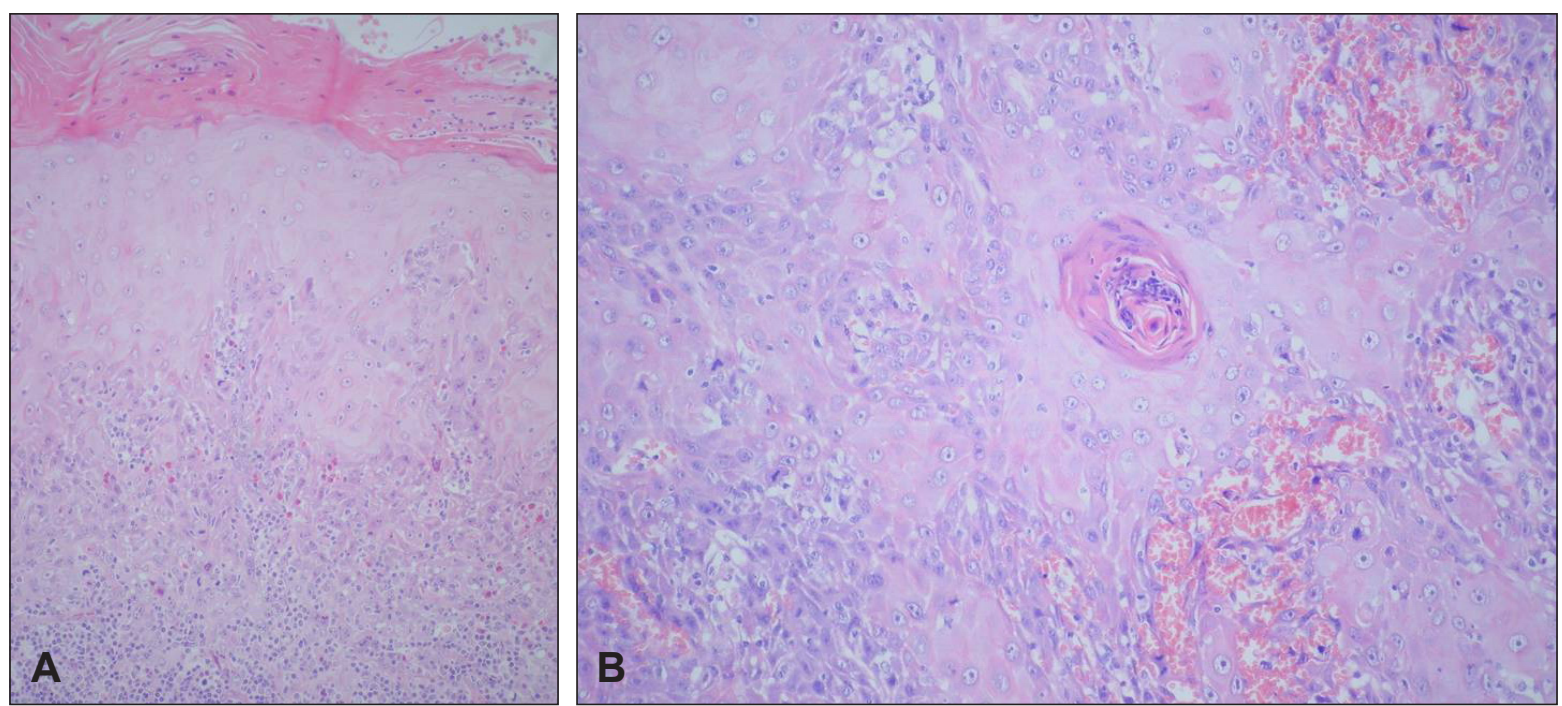

Figure 2. $\mathrm{A}$ = Histopathologic view of the lesion showing the loss of the epithelial-connective tissue (hematoxylin and eosin stain, original magnification $\mathrm{x} 40$ ).

$\mathrm{B}=$ Higher magnification showing a keratin pearl in the centre and cellular and nuclear pleomorphism (hematoxylin and eosin stain, original magnification $\mathrm{x} 100)$.

The lining epithelium of the mucosa exhibited a hyperparakeratinized stratified pavement pattern, showing areas of hyperplasia, exocytosis and hydropic degeneration leading to the final diagnosis of SCC (Figure 2).

In a view of this diagnosis, the patient was referred to the Regional Hospital of Taubaté for surgery that was performed by means of the removal of lesion observing a safety margin with peripheral osteotomy of the alveolar bone. A removable partial denture was fabricated for rehabilitation (Figures 3 and 4). As a protocol of the Hospital Oncology Service, one month after surgery of the maxilla the patient was submitted for neck dissection of regional lymph nodes. The patient was referred for radiotherapy fractionated in seven weeks each session of $50 \mathrm{~Gy}$.

At present, three years after the end of treatment,

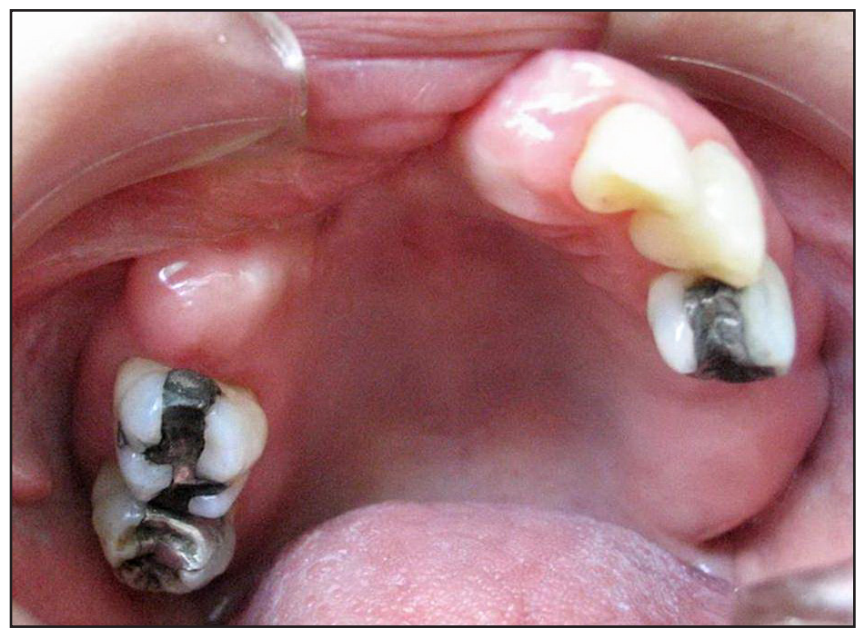

Figure 3. Postoperative image showing the healthy aspect of the mucosa adjacent to the site of the surgical procedure. the patient continues to be followed-up and does not show any sign of recurrence.

\section{DISCUSSION}

SCC is the most frequent malignant neoplasm of the mouth, corresponding to $96 \%$ of all malignant tumours in this region. In general, SCC mainly affects Caucasian male older than 40 years and is extremely rare in young patients [11]. The most affected sites in the mouth are, in decreasing order, the lower lip, lateral border of the tongue, retromolar region, floor of the mouth, and gingiva [ [3]. Although the clinical presentation of the SCC varies according to the affected site, the degree of differentiation and the invasiveness or the exophytic characteristics of most lesions are noticed

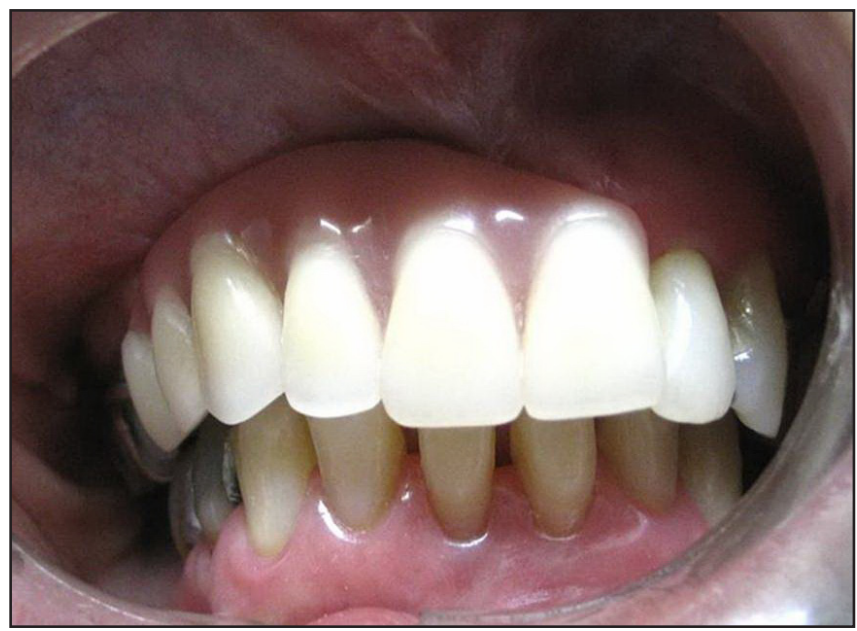

Figure 4. Rehabilitation of the patient using a removable partial denture. 
in the ulcerative stage.

SCC of the gingiva more frequently involves the mandible than the maxilla [ $[3]$ and is mainly observed in female older than 50 years [2,7]. However, some investigators have reported a higher incidence in male [4]. This controversy in the literature is mainly observed between current studies and those performed before the 1980s, a fact indicating a trend towards a higher incidence among females over the years as also observed for carcinomas involving other oral sites. One important aspect of gingival SCC is its higher risk of causing metastases and consequent death. Gingival SCC is more aggressive [6]. According to Yoon et al. [7] and Meleti et al. [11], gingival SCC does not show a strong association with classical risk factors such as actinic radiation, tobacco use, either smoked or chewed in its various forms especially when associated with excessive consumption of alcohol. Otherwise, Souza et al. [12] have reported a significant association between gingival SCC and smoking and alcohol consumption. In a study analyzing a period of 18 years (1975 and 1992), Barasch et al. [2] reported a non-significant increase in the proportion of gingival SCC compared to the total number of SCCs affecting other oral sites and also observed an increase of the tumour among females. With respect to age, in that study, gingival SCC was most frequent in the seventh decade of life.

Cases published by Wallace and Neville [1] in 1996, Levi et al. [10] in 2005 and Meleti et al. [11] in 2006 were supported by the observations regarding gingival SCC made by Barasch et al. [2] in which this neoplasm was associated to female, showing clinical aspects similar to those observed in the periodontal processes of inflammatory origin. Thus, Barasch et al. [2] suggested further studies evaluating particular factors related to gingival SCC that differ from oral SCC affecting other sites, mainly differences between genders.

A situation similar to that reported for other countries is observed in Brazil. In an analytical study of 1440 cases, Perussi et al. [13] observed an association between oral SCC and old age. Gingival SCC occurred in $11.5 \%$ of patients younger than 60 years old and in $14.5 \%$ of patients older than 60 years. This frequency is lower than the observed at other sites such as tongue and floor of the mouth. The present case, which involved a female patient diagnosed with SCC of the gingiva in the seventh decade of life, agrees with the previously reported findings.

A sui generis exception to the clinical aspects of gingival SCC mentioned above is the report of Bill et al. [14] who described a case of gingival SCC affecting a 14 year old boy with a history of gingival bleeding in the region of the left lower premolar. The lesion had an inflammatory appearance, which did not regress after removal of the orthodontic appliance. Analysis of the incisional biopsies by two anatomopathology laboratories led to the histopathological diagnoses of SCC and "atypical epithelial hyperplasia with possible malignancy", respectively. In view of this controversy, surgical removal with small safety margin of the lesion was performed, which confirmed a low-grade SCC of malignancy. Due to the involvement of the margins, the patient was submitted to a more aggressive local surgery. At the time of publication, 3 years after the second surgery, the patient presented with no signs of tumour recurrence. Tolman et al. [15] presented a case of a 29 year old female observed by an orthodontist, in whom the carcinoma began at the distal gingival margin of the left first molar and extended mesially to the middle of the second premolar; the differential diagnosis included SCC, peripheral giant cell granuloma and pyogenic granuloma. Alsharif et al. [16] reported a rare case of a 16 year old Chinese girl presenting an anterior mandibular gingival SCC. The frequency of oral SCC in young people is extremely low.

In the present case, a proliferative lesion was detected in the maxillary gingiva of a patient who did not belong to the risk group for SCC. The first symptoms reported suggested a periodontal disorder. However, more detailed assessment of clinical characteristics such as staining, verruciform surface and ulceration, which, according to Torabinejad and Rick [3] , are generally observed at the onset of gingival SCC led to its inclusion in the differential diagnosis of the lesion. SCC should be diagnosed early for a better prognosis. According to Heller, Klein and Barocas, [17] the chance for cure is favourable when the size of the lesion is less than $1 \mathrm{~cm}$. Considering that some of the more severe lesions may mimic common periodontal infections, dentists must be aware that lesions that do not respond normally to routine therapy should be biopsied.

\section{CONCLUSIONS}

Gingival squamous cell carcinoma is a condition which chance of cure is higher when carcinomatous lesions are diagnosed and treated early. In this instance dentists play an important role in early detection of gingival squamous cell carcinoma.

\section{ACKNOWLEDGMENTS AND DISCLOSURE STATEMENTS}

The authors report no conflicts of interest related to this study. 


\section{REFERENCES}

1. Wallace ML, Neville BW. Squamous cell carcinoma of the gingiva with an atypical appearance. J Periodontol. 1996 Nov;67(11):1245-8. [Medline: 8959576$]$

2. Barasch A, Gofa A, Krutchkoff DJ, Eisenberg E. Squamous cell carcinoma of the gingiva. A case series analysis. Oral Surg Oral Med Oral Pathol Oral Radiol Endod. 1995 Aug;80(2):183-7. [Medline: 7552883] [doi: $10.1016 /$ S1079-2104(05)80200-8]

3. Torabinejad M, Rick GM. Squamous cell carcinoma of the gingiva. J Am Dent Assoc. 1980 Jun;100(6):870-2. [Medline: 6929837]

4. Misra S, Chaturvedi A, Misra NC. Management of gingivobuccal complex cancer. Ann R Coll Surg Engl. 2008 Oct;90(7):546-53. Epub 2008 Aug 12. Review. [Medline: 18701010] [doi: 10.1308/003588408X301136] [FREE Full Text]

5. Helldén L, Jonsson R. A papillary-verrucous lesion in the gingiva, developing into squamous cell carcinoma. J Clin Periodontol. 1987 Jan;14(1):56-61. [Medline: 3468130] [doi: 10.1111/j.1600-051X.1987.tb01515.x]

6. Pathak KA, Mathur N, Talole S, Deshpande MS, Chaturvedi P, Pai PS, Chaukar DA, D'Cruz AK. Squamous cell carcinoma of the superior gingival-buccal complex. Oral Oncol. 2007 Sep;43(8):774-9. Epub 2007 Feb 15. [Medline: 17306606] [doi: 10.1016/j.oraloncology.2006.09.009]

7. Yoon TY, Bhattacharyya I, Katz J, Towle HJ, Islam MN. Squamous cell carcinoma of the gingiva presenting as localized periodontal disease. Quintessence Int. 2007 Feb;38(2):97-102. [Medline: 17263148]

8. Lubek J, El-Hakim M, Salama AR, Liu X, Ord RA. Gingival carcinoma: retrospective analysis of 72 patients and indications for elective neck dissection. Br J Oral Maxillofac Surg. 2010 May 10. [Epub ahead of print]. [Medline: 20462676] [doi: 10.1016/j.bjoms.2010.04.005]

9. Mourouzis C, Pratt C, Brennan PA. Squamous cell carcinoma of the maxillary gingiva, alveolus, and hard palate: is there a need for elective neck dissection? Br J Oral Maxillofac Surg. 2010 Jul;48(5):345-8. Epub 2009 Aug 7. [Medline: 19665264] [doi: 10.1016/j.bjoms.2009.07.012]

10. Levi PA Jr, Kim DM, Harsfield SL, Jacobson ER. Squamous cell carcinoma presenting as an endodontic-periodontic lesion. J Periodontol. 2005 Oct;76(10):1798-804. [Medline: 16253104] [doi: 10.1902/jop.2005.76.10.1798]

11. Meleti M, Corcione L, Sesenna E, Vescovi P. Unusual presentation of primary squamous cell carcinoma involving the interdental papilla in a young woman. Br J Oral Maxillofac Surg. 2007 Jul;45(5):420-2. Epub 2006 Feb 17. [Medline: 16483701 ] [doi: 10.1016/j.bjoms.2005.12.006]

12. Souza RP, Moreira PTB, Paes Junior AJO, Pacheco Neto CM, Soares AH, Rapoprt A. [Gingival squamous cell carcinoma: imaging analysis of seven patients] Radiol Bras 2003 Aug;36(4):225-7. [doi: 10.1590/S0100-39842003000400008] [FREE Full Text]

13. Perussi MR, Denardin OV, Fava AS, Rapoport A. [Squamous cell carcinoma of the mouth in the elderly in São Paulo]. Rev Assoc Med Bras. 2002 Oct-Dec;48(4):341-4. Epub 2003 Jan 28. Portuguese. [Medline: 12563463] [doi: 10.1590/S0104-42302002000400041] [FREE Full Text]

14. Bill TJ, Reddy VR, Ries KL, Gampper TJ, Hoard MA. Adolescent gingival squamous cell carcinoma: Report of a case and review of the literature. Oral Surg Oral Med Oral Pathol Oral Radiol Endod. 2001 Jun;91(6):682-5. Review. [Medline: 11402282] [doi: 10.1067/moe.2001.115029]

15. Tolman A, Jerrold L, Alarbi M. Squamous cell carcinoma of attached gingiva. Am J Orthod Dentofacial Orthop. 2007 Sep;132(3):378-81. [Medline: 17826607] [doi: 10.1016/j.ajodo.2007.04.030]

16. Alsharif MJ, Jiang WA, He S, Zhao Y, Shan Z, Chen X. Gingival squamous cell carcinoma in young patients: report of a case and review of the literature. Oral Surg Oral Med Oral Pathol Oral Radiol Endod. 2009 May;107(5):696-700. Epub 2009 Mar 9. Review. [Medline: 19272815] [doi: 10.1016/j.tripleo.2008.12.048]

17. Heller AN, Klein A, Barocas A. Squamous cell carcinoma of the gingiva presenting as an endoperiodontic lesion. J Periodontol. 1991 Sep;62(9):573-5. [Medline: 1941498]

\section{To cite this article:}

Cabral LA, Carvalho LF, Salgado JA, Brandão AA, Almeida JD. Gingival Squamous Cell Carcinoma: a Case Report.

J Oral Maxillofac Res 2010 (Jul-Sep);1(3):e6

URL: http://www.ejomr.org/JOMR/archives/2010/3/e6/e6ht.pdf

doi: $10.5037 /$ jomr.2010.1306 
Copyright (C) Cabral LA, Carvalho LF, Salgado JA, Brandão AA, Almeida JD. Accepted for publication in the JOURNAL OF ORAL \& MAXILLOFACIAL RESEARCH (http://www.ejomr.org), 7 July 2010.

This is an open-access article, first published in the JOURNAL OF ORAL \& MAXILLOFACIAL RESEARCH, distributed under the terms of the Creative Commons Attribution-Noncommercial-No Derivative Works 3.0 Unported License, which permits unrestricted non-commercial use, distribution, and reproduction in any medium, provided the original work and is properly cited. The copyright, license information and link to the original publication on (http://www.ejomr.org) must be included. 